\title{
Peran Kelompok Nelayan dalam Kegiatan Pariwisata terhadap Peluang Usaha dan Kerja
}

\section{The Role of Fishermen group in Tourism for Business Opportunities and Employment}

\author{
Fadil Arfianto ${ }^{1}$, Amiruddin Saleh ${ }^{1}$ \\ ${ }^{1}$ Departemen Sains dan Pengembangan Masyarakat, \\ Fakultas Ekologi Manusia (FEMA) - IPB
}

\begin{abstract}
The purpose of this study was to analyze the role of fishermen in the tourism activities of the business and employment opportunities. This study also examines the relationship between the characteristics of the group members and group elements with the role of fishermen, where the research was conducted on a group cruise boat belonging to the Organization of Boat Cruise Pangandaran (OBCP) Pangandaran Village. On testing the characteristics of group members to the role of fishermen, there was a real relationship. In the test group elements with the role of fishermen, there was a real relationship unless the relationship norms/ rules of the group with the group supporting service units were not real relationships. Finally, in testing the role of fishermen and businesses and employment opportunities, there was a real relationship, this was evidenced by the presence of several members of the group who has other business other than as a fisherman or a boat cruise as homestays, restaurants and stalls.
\end{abstract}

Keywords: tourism, fishing groups, businesses or work

\begin{abstract}
Abstrak
Tujua penelitian ini adalah untuk menganalisis peran kelompok nelayan dalam kegiatan pariwisata terhadap peluang usaha dan kerja. Penelitian ini juga bertujuan melihat hubungan antara karakteristik anggota kelompok dan elemen-elemen kelompok dengan peran kelompok nelayan dimana penelitian ini dilakukan pada kelompok perahu pesiar yang tergabung ke dalam Organisasi Perahu Pesiar Pangandaran (OP3) Desa Pangandaran. Pada pengujian karakteristik anggota kelompok dengan peran kelompok nelayan, terdapat hubungan yang nyata. Pada pengujian elemen-elemen kelompok dengan peran kelompok nelayan, terdapat hubungan yang nyata terkecuali hubungan norma/aturan kelompok dengan unit jasa penunjang kelompok terdapat hubungan tidak nyata. Peran kelompok nelayan dan peluang usaha dan kerja, terdapat hubungan nyata, hal ini dibuktikan dengan adanya beberapa anggota kelompok yang memiliki usaha lainnya selain sebagai nelayan atau perahu pesiar seperti homestay, rumah makan dan warung/kios.
\end{abstract}

Kata kunci: pariwisata, kelompok nelayan, usaha atau kerja

\section{Pendahuluan}

Perkembangan sektor kelautan merupakan bagian penting dalam pembangunan nasional. Sektor kelautan dan perikanan tidak hanya menawarkan produk-produk barang sebagai hasil perikanan, tetapi juga sektor jasa yang juga berperan dalam pemasukan devisa negara. Pariwisata menurut BPS (2012) merupakan keseluruhan rangkaian kegiatan yang berhubungan dengan gerakan manusia yang melakukan perjalanan atau persinggahan sementara dari tempat tinggalnya ke suatu atau beberapa tempat tujuan di luar lingkungan tempat tinggalnya yang didorong oleh beberapa keperluan atau motif tanpa bermaksud mencari nafkah tetap. Kebijakan pembangunan pariwisata nasional dan daerah sudah menjadi cara untuk menggerakkan ekonomi terutama dalam perannya menciptakan lapangan pekerjaan dan kesempatan kerja bagi masyarakat. Pariwisata saat ini menjadi sektor yang cukup penting melihat perkembangannya saat ini baik skala global maupun lokal mengalami pertumbuhan yang sangat pesat.

Menurut data Kementerian Kebudayaan dan Pariwisata (2013) menunjukkan sektor pariwisata berada diurutan keempat sebagai penghasil devisa terbesar di Indonesia dengan total pendapatan 7,6 milliar dollar (USD). Indonesia menawarkan wisata alam, wisata budaya, wisata sejarah dan lainnya yang tersebar di seluruh pelosok negeri, baik yang telah dikelola dengan baik maupun belum dikelola dan belum terjamah oleh manusia.

Kawasan bahari yaitu kawasan pesisir yang sangat diminati oleh wisatawan baik wisatawan lokal maupun mancanegara dan memiliki prospek ekonomi yang sangat baik dalam pengelolaannya menjadi tempat wisata. Peran pemerintah atau masyarakat daerah sangat penting dalam pengembangannya, karena pembangunan sektor wisata bahari diharapkan

${ }^{1}$ Korespondensi penulis E-mail: amiruddin_ipb@yahoo.co.id 
dapat meningkatkan Pendapatan Asli Daerah (PAD) dan memperbaiki kesejahteraan hidup masyarakat terutama nelayan. Pengelolaan wisata bahari dapat pula ikut mengembangkan berbagai jenis lapangan pekerjaan bagi warga masyarakat setempat. Idealnya dalam pengelolaan wisata, masyarakat setempat atau lokal ikut berpartisipasi atau terlibat dalam pengelolaannya, sebab masyarakat lokal tinggal di sekitar atau di dalam obyek wisata tersebut.

Kehidupan nelayan sangat bergantung kepada cuaca, jika cuaca buruk dan tidak memungkinkan bagi mereka untuk melaut sehingga pendapatan mereka menurun. Untuk itu sebagian dari nelayan berpikiran untuk mencari usaha atau pekerjaan lainnya yang dapat menambah pendapatan, salah satu alternatifnya adalah memanfaatkan potensi wisata yang ada dan bergerak dalam pengelolaan wisata tersebut.

Peran kelompok nelayan sangat menentukan bagi keberhasilan para nelayan dalam peran mereka pada kegiatan sektor pariwisata. Menurut Keputusan menteri kelautan dan perikanan republik Indonesia Nomor KEP.14/MEN/2012, fungsi kelembagaan pelaku utama perikanan mempunyai fungsi sebagai wadah proses pembelajaran, wahana kerjasama, unit penyedia sarana dan prasarana produksi perikanan, unit produksi perikanan, unit pengolahan dan pemasaran, unit jasa penunjang, organisasi kegiatan bersama, dan kesatuan swadaya dan swadana. Peran kelompok yang ditekankan dalam hal ini adalah peran kelompok sebagai wahana kerjasama dan unit jasa penunjang. Dibutuhkan indikator untuk mengukur atau melihat peran kelompok tersebut dalam usahanya di kegiatan pariwisata seperti peran pemimpin kelompok, peranan tugas kelompok, dan norma/aturan kelompok yang baik.

Peran kelompok nelayan dalam kegiatan pariwisata yang dapat memberikan peluang usaha dan kerja di sektor pariwisata perlu dilihat implementasinya di suatu daerah tujuan wisata yang ada di Jawa Barat yaitu Desa Pangandaran, Kecamatan Pangandaran, Kabupaten Pangadaran, Provinsi Jawa Barat.

\section{Metode Penelitian}

Penelitian ini menggunakan pendekatan kuantitatif yang didukung dengan pendekatan kualitatif dalam pengumpulan datanya. Pendekatan kuantitatif dilakukan melalui penelitian survei yaitu penelitian yang mengambil sampel dari satu populasi dan menggunakan kuesioner sebagai alat pengumpulan data yang pokok (Singarimbun \& Effendi, 2008). Pengumpulan data kuantitatif dalam penelitian ini dilakukan melalui metode survei kepada masyarakat dengan menggunakan kuesioner. Melalui pendekatan ini dilakukan pengambilan dokumen dan wawancara mendalam kepada informan. Pendekatan kuantitatif dan kualitatif ini berguna untuk mengetahui peran kelompok nelayan dalam kegiatan pariwisata, mengetahui macam usaha yang dikerjakan oleh kelompok nelayan yang aktif dalam kegiatan pariwisata, mengetahui hubungan elemen-elemen kelompok yaitu indikator kepemimpinan melalui peran pemimpin, peranan tugas kelompok, dan norma/aturan kelompok dengan peran kelompok nelayan dan mengetahui hubungan peran kelompok nelayan dalam fungsinya sebagai wahana kerjasama dan unit jasa penunjang dengan peluang usaha dan kerja pada sektor pariwisata. Observasi adalah melakukan pengamatan secara langsung ke obyek penelitian untuk melihat aktivitas yang dilakukan.

Data primer dan sekunder yang diperoleh diolah dan kemudian dianalisa secara deskriptif. Menurut Riduwan dan Sunarto (2011), Analisis deskriptif adalah analisis yang menggambarkan suatu data yang akan dibuat baik sendiri maupun secara kelompok. Data yang diperoleh melalui pendekatan kualitatif yaitu dengan wawancara mendalam dan observasi disajikan secara deskriptif untuk mendukung dan memperkuat analisis kuantitatif.

Populasi dari penelitian ini adalah seluruh masyarakat nelayan Desa Pangandaran, Kecamatan Pangandaran, Kabupaten Ciamis, Jawa Barat yang merupakan anggota kelompok perahu pesiar dalam Organisasi Perahu Pesiar Pangandaran (OP3). Unit analisis penelitian yaitu anggota kelompok nelayan yang aktif dalam kegiatan usaha atau kerja di luar sektor perikanan khususnya usaha atau kerja dalam bidang pariwisata. OP3 adalah organisasi nelayan yang mengakomodasi kegiatan pariwisata di Pangandaran khususnya Desa Pangandaran. Usaha pariwisata yang dikelola oleh OP3 adalah jasa perahu wisata/perahu pesiar. Jumlah anggota OP3 secara keseluruhan sebanyak 518 orang yang dibagi ke dalam tujuh kelompok perahu pesiar dengan wilayah kerja yang berbeda yaitu sebagian besar 
cakupan wilayahnya terdapat di Desa Pangandaran dan Desa Pananjung. Masing-masing kelompok melayani para pengunjung yang berada di wilayah kerja mereka.

Pengambilan responden dengn menggunakan metode pengambilan sampel acak sederhana (Simple Random Sampling) agar populasi mempunyai kesempatan yang sama untuk dipilih sebagai sampel. Responden yang dipilih sebesar 7\% dari jumlah populasi yaitu sebanyak 36 orang yang tergabung dalam kelompok nelayan yang aktif dalam kegiatan pariwisata. Pemilihan responden sebanyak 36 orang dari jumlah populasi dikarenakan anggota nelayan tersebut memiliki banyak persamaan atau homogen, sehingga pemilihan 36 responden dirasakan cukup untuk dapat mewakili pernyataan-pernyataan dalam kuesioner tergolong kategori valid. Uji validitas dilakukan pada 10 orang anggota kelompok lima perahu pesiar Pangandaran yang memiliki wilayah operasi di Desa Pananjung, hal ini dikarenakan Desa Pananjung tidak masuk wilayah penelitian.

Uji reliabilitas digunakan untuk melihat sejauh mana hasil pengukuran telah konsisten bila dilakukan pengukuran lagi. Pengujian reliabilitas dilihat dari kuat atau tidaknya nilai koefisien reliabilitas split-half Guttman (rSHG), menyatakan dimensi elemen-elemen kelompok memiliki tingkat reliabilitas tergolong tinggi (reliabel), yaitu nilai koefisien reliabilitas split-half Guttman (rSHG) = 0,843 , sedangkan pada dimensi peran kelompok nelayan tergolong moderat dengan nilai koefisien reliabilitas split-half Guttman (rSHG) $=0,519$.

Pengolahan data dilakukan dengan langkah, yaitu pertama, melakukan pengkodean kemudian memasukkan data ke dalam berkas data. Kedua, membuat tabel frekuensi. Ketiga mengedit yakni mengoreksi kesalahan-kesalahan yang ditemui setelah membaca hasil tabel frekuensi. Data yang diperoleh akan dianalisis dengan teknik berikut:

1. Tabel frekuensi, untuk menganalisis data primer dan sekunder.

2. Uji Chi Square untuk menganalisis hubungan antar peubah dengan data nominal dengan data ordinal, yaitu hubungan peubah jabatan dalam kelompok dengan dimensi peran kelompok nelayan dan juga dimensi elemen-elemen kelompok, selain itu juga untuk melihat hubungan antara dimensi peran kelompok nelayan dengan dimensi peluang usaha dan kerja.

3. Uji korelasi rank Spearman untuk melihat hubungan nyata antar peubah. Analisis data ini dilakukan untuk melihat hubungan antara karakteristik anggota kelompok dengan peran kelompok nelayan dan elemen-elemen kelompok.

Uji korelasi rank Spearmandigunakan untuk melihat hubungan antar peubah dengan data ordinal dan data interval yang diubah menjadi data ordinal. Uji korelasi chi square digunakan untuk melihat hubungan antar peubah dengan data nominal dengan data ordinal. Uji korelasi rank Spearman dan chi square digunakan untuk menentukan hubungan antara kedua peubah (peubah independen dan peubah dependen). Korelasi positif menunjukkan hubungan yang searah antara dua peubah yang diuji, yang berarti semakin besar peubah bebas (peubah independen) maka semakin besar pula peubah terikat (peubah dependen). Sementara itu, korelasi negatif menunjukkan hubungan yang tidak searah, yang berarti jika peubah bebas besar maka peubah terikat menjadi kecil (Rakhmat, 1997). Tingkat kesalahan yang digunakan dalam penelitian ini adalah sebesar lima persen atau pada taraf nyata $\alpha=0,05$, yang berarti memiliki tingkat kepercayaan 95\%.

\section{Hasil dan Pembahasan}

Desa Pangandaran adalah salah satu tujuan wisata yang cukup menawan, banyak penduduk dari daerah lain berdatangan mengadu nasib di Desa Pangandaran, kebanyakan dari mereka berusaha menjadi pedagang di pinggiran pantai atau bekerja menjadi karyawan hotel, tak sedikit pula yang ikut menjadi buruh nelayan atau yang lebih dikenal dengan sebutan "Jonggol," sehingga tidak heran jika tiap tahunnya selalu banyak orang yang datang ke Pangandaran untuk mengadu nasib.

Kedatangan dan juga kepindahan penduduk ini tentu saja ikut mempengaruhi perkembangan jumlah penduduk suatu wilayah termasuk di Desa Pangandaran. Jumlah penduduk Desa Pangandaran tahun 2013 sebanyak 10.373 dengan pembagian jumlah penduduk laki-laki dengan perempuan memiliki perbandingan jumlah yang tidak terlalu jauh berbeda yaitu laki-laki sebesar 5.231 orang sedangkan perempuan sebesar 5.142 orang sehingga terdapat selisih 89 orang. 
Desa Pangandaran merupakan Desa wisata primadona di Jawa Barat. Obyek wisata unggulan di Desa Pangandaran adalah pantai barat Pangandaran, pantai timur Pangandaran dan cagar alam Pananjung. Sektor pariwisata merupakan sektor utama dalam penyumbang Pendapatan Asli Daerah (PAD). Desa Pangandaran memiliki berbagai keistimewaan seperti; dapat melihat terbit dan tenggelamnya matahari dari satu tempat yang sama, pantainya landai dengan air yang jernih dan memungkinkan kita untuk berenang dengan aman, terdapat pantai dengan hamparan pasir putih, tersedia tim penyelamat wisata pantai, sarana jalan yang baik, terdapat taman laut dengan ikan-ikan dan kehidupan laut yang indah.

Adanya faktok-faktor penunjang tersebut, maka wisatawan yang datang di Pangandaran dapat melakukan kegiatan yang beraneka ragam seperti berenang, berperahu pesiar, memancing, keliling dengan sepeda, jet ski dan lain-lain. Salah satu kegiatan cukup menarik yang bisa di lakukan di pantai Pangandaran adalah ikut merasakan sensasi menarik jaring pukat milik nelayan Pangandaran.

Fasilitas pendukung wisata lainnya yang terdapat di Desa Pangandaran adalah lapang parkir yang cukup luas, hotel atau penginapan, restoran, pondok wisata dengan tarif bervariasi, pelayanan pos, telekomunikasi dan money changer, pusat informasi pariwisata, bumi perkemahan, pasar wisata yang menjual souvenir-souvenir khas Pangandaran dan pasar ikan yang menjual ikan tangkapan nelayan maupun hasil olahan ikan seperti ikan asin ataupun makanan laut lainnya.

Acara tradisional yang cukup menarik para wisatawan untuk berkunjung ke Desa Pangandaran adalah hajat laut, yakni upacara yang dilakukan nelayan di Pangandaran sebagai perwujudan rasa terima kasih mereka terhadap karunia tuhan dengan cara melarutkan sesajen ke laut lepas. Acara ini biasa dilaksanakan pada tiap-tiap bulan muharam, dengan mengambil tempat di pantai timur Pangandaran. Acara pariwisata bertaraf internasional yang selalu dilaksanakan di sini adalah festival layang-layang Internasional (Pangandaran International Kite Festiva) dengan berbagai kegiatan pendukungnya yang biasa dilakukan pada bulan juni atau juli.

Organisasi Perahu Pesiar Pangandaran (OP3) pertama kali didirikan sekitar tahun 1974 dan mendapatkan pengakuan kelembagaan sah secara hukum pada tanggal 4 November 2009. Tujuan
Organisasi ini dimaksud menggali dan menumbuh kembangkan seluruh potensi masyarakat dengan tujuan dapat menjadi karya nyata dengan masa bakti kepengurusan organisasi ini adalah lima tahun sekali. Organisasi perahu pesiar hadir sebagai salah satu penyedia jasa bagi para wisatawan yang akan menikmati indahnya pesona laut Pangandaran dan sekitarnya karena obyek wisata Pantai Pangandaran dan sekitarnya adalah salah satu daya tarik wisata Provinsi Jawa Barat yang pada setiap tahunnya tidak pernah sepi dari kunjungan wisatawan baik domestik maupun mancanegara. Lemahnya perekonomian masyarakat di daerah membuat pelaksanaan usaha tanpa banyak dukungan dan tanpa dikelola dengan baik akan berdampak pada sejauh mana penghasilan yang didapat, sehingga target yang diharapkan adalah bagaimana organisasi perahu pesiar bisa menjadi kebutuhan bagi keberadaan wisata Pantai Pangandaran.

Pada tahun 2009, atas inisiatif bapak Dedi Hermawan selaku ketua OP3 yang baru dilantik pada saat itu membagi seluruh anggota OP3 yang berjumlah 518 orang ke dalam tujuh kelompok dengan wilayah kerja yang berbeda. Kelompok $1,2,3,4,5$ dan tujuh berada di wilayah pantai barat Pangandaran, sedangkan kelompok enam berada di wilayah pantai timur Pangandaran, hal ini bertujuan untuk mempermudah pelaksanaan kegiatan atau usaha perahu pesiar. Setiap satu perahu pesiar Pangandaran memiliki jumlah awak sebanyak dua sampai empat orang yang bertugas melayani para wisatawan yang menggunakan perahu pesiar tersebut. Perahu pesiar yang digunakan oleh setiap kelompok adalah jenis GT 1 dan harus memiliki surat ijin pesiar dari Dinas Perhubungan bagian kelautan. Setiap perahu harus melakukan perpanjangan ijin setiap tahunnya dan surat ijin perahu pesiar apabila tiga tahun berturut-turut tidak memenuhi perpanjangan ijin maka pemilik/juragan berkewajiban untuk memperbaiki dan memperbaiki ijin tersebut.

\section{Karakteristik Responden dan Elemen-Elemen Kelompok}

\section{Umur}

Umur adalah selisih dari usia antara tahun anggota kelompok dilahirkan dengan tahun pada 
saat penelitian dilaksanakan. Berdasarkan data yang didapat usia responden Desa Pangandaran antara 23-41 tahun sehingga dibagi menjadi tiga kategori yaitu usia muda (23-28 tahun), dewasa awal (29-32 tahun) dan dewasa akhir (33-41 tahun) yang masuk ke dalam golongan usia muda adalah sebanyak 12 orang $(33,33 \%)$, golongan dewasa awal sebanyak 13 orang $(36,11 \%)$, dan golongan dewasa akhir sebanyak 11 orang (30,56\%). Terlihat bahwa anggota kelompok didominasi oleh anggota yang tergolong ke dalam usia dewasa awal yang sudah melaut atau sebagai nelayan sejak remaja.

\section{Tingkat Pendidikan}

Tingkat pendidikan adalah tahun tempuh anggota kelompok dalam memperoleh pendidikan formal yang terstruktur. Tingkat pendidikan dikategorikan rendah (tamat SD), sedang (tamat SMP) dan tinggi (tamat SMA). Hasil penelitian di lapangan menunjukkan bahwa sebanyak tujuh orang nelayan atau $19,44 \%$ responden tergolong dalam kategori berpendidikan rendah, yaitu tidak tamat sekolah dasar atau hanya mencapai jenjang pendidikan tertinggi di Sekolah Dasar. Sebanyak 15 orang nelayan atau $41,67 \%$ responden berpendidikan sedang, yaitu tamat Sekolah Menengah Pertama/ sederajat dan sebanyak 14 orang nelayan atau 38,89 $\%$ responden yang tergolong berpendidikan tinggi, atau tamat Sekolah Menengah Atas/sederajat. Tingkat pendidikan di Desa Pangandaran cukup tinggi karena dari responden yang didapat cukup banyak nelayan yang menamatkan pendidikan hingga tingkat SMP dan SMA dengan selisih yang sangat sedikit, hal ini menunjukkan keinginan masyarakat untuk sekolah cukup tinggi meskipun kebanyakan dari mereka setelah tamat SMP atau SMA langsung terjun ke dunia kerja atau mengikuti jejak orang tuanya sebagai nelayan dan tidak melanjutkan ke tingkat pendidikan yang lebih tinggi. Fasilitas pendukung pendidikan juga sudah cukup memadai sehingga mudah bagi mereka untuk mengakses pendidikan di daerah mereka.

\section{Jabatan dalam Kelompok}

Jabatan di dalam kelompok adalah posisi yang diberikan sebagai tanggung jawab atas tugas yang diemban di dalam kelompok. Dibedakan ke dalam dua kategori yaitu pengurus kelompok (ketua, wakil ketua, sekretaris dan bendahara, SAR, dan lainnya) dan anggota kelompok. Hasil penelitian di lapangan menunjukkan terdapat lima pengurus kelompok yang menjadi responden atau $13,89 \%$, yang terbagi menjadi tiga responden menjabat sebagai ketua kelompok, satu orang menjabat sebagai wakil ketua dan seorang responden sebagai SAR. Berdasarkan data yang didapat terdapat 31 orang sebagai anggota kelompok atau $86,11 \%$. Dalam masing-masing kelompok perahu pesiar memiliki struktur yang jelas denga masa bakti kepengurusan selama lima tahun. Pemilihan ketua maupun struktur kelompok lainnya dilakukan secara musyawarah. Selain terdapat ketua, wakil ketua, sekretaris dan bendahara dalam kelompok terdapat juga tim SAR yang berfungsi mengawasi dan mengantisipasi terjadinya hal yang tidak diinginkan bagi para pengunjung. Setiap kelompok terdapat tiga orang SAR yang bertugas mengantisipasi terjadinya hal yang tidak diinginkan yang dialami oleh para pengunjung.

\section{Lama Keanggotaan}

Lama keanggotaan adalah lamanya setiap anggota kelompok bergabung dalam kelompok hingga penelitian ini dilakukan dalam satuan bulan. Data yang didapat lama keanggotaan kelompok di antara 8-41 bulan. Dibedakan ke dalam kategori rendah (8-32 bulan) dan tinggi (33-42 bulan). Organisasi perahu pesiar Pangandaran (OP3) didirikan sekitar tahun 1974 dan pada tahun 2009 atas inisiatif keua OP3 dan untuk mempermudah pelaksanaan kegiatan organisasi maka dibentuklah tujuh kelompok perahu pesiar dengan wilayah operasi yang berbeda, sehingga sebagian besar anggota adalah anggota organisasi terdahulu yang memiliki pengalaman keanggotaan tergolong tinggi atau cukup lama sejak kelompok dibentuk hingga sekarang.

\section{Elemen-elemen Kelompok}

\section{Peran Pemimpin}

Peran dari pemimpin adalah usaha yang dilakukan pemimpin dalam mengkoodinir, memberi informasi dan menjaga kekompakkan anggota kelompoknya. Indikator yang digunakan dalam peran 
pemimpin adalah mencetuskan ide atau sebagai seorang kepala, mengaktifkan anggota, mengawasi kegiatan, memberi semangat untuk mencapai tujuan, mewakili kelompok, dan memberi tanggung jawab. Dikategorikan ke dalam rendah (jika total skor antara 20-22), sedang (jika total skor antara 23-25) dan tinggi (jika total skor antara 26-28). Berdasarkan data tersebut menyatakan bahwa kepemimpinan melalui peran pemimpin kelompok perahu pesiar tergolong sedang atau cukup berperan. Pemimpin masing-masing memiliki masa bakti selama lima tahun. Melalui penelitian ini melihat pandangan dari anggota terhadap aspek kepemimpinan yang dimiliki pemimpin kelompok mereka adalah peran pemimpin dalam mencetuskan ide dalam merencanakan kegiatan, pemimpin memberikan kesempatan kepada anggotanya dalam menyampaikan ide atau gagasan, keikutsertaan pemimpin dalam kegiatan kelompok, pengawasan terhadap anggotanya, pemberian semangat kepada anggotanya, tidak memaksakan kehendak, dalam pengambilan keputusan dan bentuk pemberian tanggung jawab kepada anggotanya. Kesemua aspek tersebut dirasa cukup baik dilakukan oleh para ketua kelompok ataupun pengurus kelompok menurut para anggotanya.

\section{Peranan Tugas Kelompok}

Peran tugas kelompok adalah kemampuan yang dilakukan setiap anggota kelompok dalam melakukan tugasnya di dalam kelompok. Indikator yang digunakan dalam peran tugas kelompok adalah penyetus-penyumbang, pencari informasi, pemberi informasi, pemberi pendapat, koordinator, pengkritik-penilai, dan penggerak. Peran tugas kelompok dibedakan ke dalam kategori rendah (jika total skor antara 18-20), sedang (jika total skor antara 21-23) dan tinggi (jika total skor antara 2426). Peranan tugas kelompok tergolong ke dalam kategori rendah karena menurut pandangan angota kelompok peran pemimpin yang cukup menonjol dalam kelompok membuat setiap anggota kelompok merasa tugas kelompok dapat terselesaikan antara pemimpin dengan beberapa anggotanya, sehingga banyak anggota tidak ikut serta dalam menjalankan tugas kelompok secara bersama-sama. Pertemuan rutin dalam ataupun antar kelompok yang jarang dapat membuat hal ini bisa saja terjadi, dengan kata lain peran ketua menjadi penting.

\section{Norma/Aturan Kelompok}

Norma atau aturan, ialah cara yang ditetapkan untuk dipatuhi dan dijalankan yang menetapkan perilaku apa yang dapat diterima kelompok/tidak dapat diterima kelompok. Ukuran yang digunakan dalam peubah ini berdasarkan dipatuhi atau tidak dipatuhinya aturan-aturan yang telah ditetapkan dalam kelompok oleh anggotanya. Indikator norma/ aturan yaitu bentuk aturan, pemahaman isi aturan, dan penerapan aturan. Norma/aturan dikategorikan menjadi rendah (jika total skor antara 14-16), sedang (jika total skor antara 17-19) dan tinggi (jika total skor antara 20-22). Dalam norma/aturan kelompok yang dilihat adalah aspek kejelasan aturan, pemahaman aturan, peringatan aturan, kesediaan menerima aturan, keberanian mengakui kesalahan dan bersedia menerima hukuman jika melanggar. Berdasarkan pandangan anggota yang didapat norma/aturan kelompok secara umum tergolong cukup baik dalam penerapannya, karena semua responden menyatakan paham akan isi dari aturan kelompok yang telah ditetapkan begitu juga dengan konsekuensi yang mereka dapat jika melanggar aturan tersebut. Setiap anggota kelompok berusaha untuk menghindari pelanggaran aturan dengan menuruti normanorma yang berlaku dalam menjalankan pekerjaan mereka seperti tidak membawa pengunjung lebih dari 10 orang dalam perahu pesiar, penggunaan alat pengaman atau pelampung bagi pengunjung, pemakaian bendera merah putih pada perahu dan lainnya.

\section{Peran Kelompok Nelayan}

\section{Wahana Kerjasama}

Wahana kerjasama adalah bentuk peran dari kelompok sebagai wadah kerjasama antar anggota kelompok dalam upaya mengembangkan kelompok dan membina kehidupan kelompok. Indikator peran kelembagaan sebagai wahana kerjasama yaitu kerjasama dalam pencarian informasi usaha pariwisata, kerjasama dalam penyediaan komoditi atau peralatan usaha dan kerja, dan kerjasama dalam pengelolaan usaha kelompok. Dikategorikan ke dalam rendah (jika total skor antara 13-14), sedang (jika total skor antara 15-16) dan tinggi (jika total skor antara 17-18). Wahana kerjasama kelompok 
secara umum tergolong rendah, hal ini dapat terjadi karena kurangnya pertemuan rutin kelompok yang dapat lebih mengakrabkan kelompok dan hanya segelintir anggota yang dianggap sebagai tetua atau yang dianggap paling berpengalaman termasuk pemimpin kelompok yang lebih menonjol dalam mengatur semua kegiatan, yang diyakini dapat mewakili kelompok dalam menyelesaikan pekerjaan kelompok secara umum, sehingga anggota kelompok berpandangan merasa tidak perlu terlalu melibatkan diri. Hal ini menyebabkan peran kelompok sebagai wahana kerjasama dianggap kurang.

\section{Unit Jasa Penunjang}

Peran kelompok nelayan sebagai unit jasa penunjang adalah bentuk peran kelompok sebagai kelompok unit usaha yang mengelola usaha di luar usaha pokoknya seperti usaha-usaha dalam kegiatan pariwisata. Indikator peran kelembagaan sebagai unit jasa penunjang yaitu melihat pandangan anggota tentang perlu atau tidaknya memiliki usaha penunjang di sektor perdagangan, akomodasi, transportasi, makanan, dan penyewaan peralatan penunjang wisata. Dikategorikan ke dalam rendah (jika total skor antara 11-13), sedang (jika total skor antara 14-16) dan tinggi (jika total skor antara 17-19). unit jasa penunjang kelompok perlu dikembangkan. Hal ini dapat terjadi karena terdapatnya 10 anggota kelompok yang telah memiliki usaha tambahan untuk menunjang ekonomi mereka, ini terjadi karena mereka berpandangan kebutuhan yang semakin meningkat karena semakin banyaknya pengunjung yang terus berdatangan ke

Pangandaran, sehingga peluang ini dianggap sebagai suatu kesempatan untuk mendapatkan keuntungan yang lebih jika dilakukan. Berdasarkan data yang didapat usaha tambahan yang mereka usahakan secara mandiri seperti membuka rumah makan, homestay dan warung. Unit jasa penunjang kelompok diperlukan karena kebutuhan anggotanya.

\section{Peran Kelompok Nelayan Perahu Pesiar Pangandaran dalam Kegiatan Pariwisata}

Berkembanganya fasilitas sektor pariwisata di Desa Pangandaran saat ini membuat tingkat kedatangan pengujung semakin banyak untuk berwisata di Pangandaran. Kesempatan ini tentu memberi keuntungan bagi masyarakat sekitar. Berkembangnya pariwisata di Desa Pangandaran ini tidak lepas dari peran nelayan khususnya para nelayan yang tergabung ke dalam kelompok perahu pesiar Organisasi Perahu Pesiar Pangandaran (OP3). Fasilitas perahu pesiar atau wisata saat ini menjadi sarana pariwisata yang cukup diminati di Pangandaran, dengan perahu pesiar tersebut para wisatawan dapat memancing, melihat keindahan bawah laut dengan snorkling, maupun berkeliling melihat potensi pariwisata lainnya di sekitar Desa Pangandaran seperti pantai Pasir Putih, pantai Batu Karas, Batu Hiu, Green Canyon maupun berkeliling mengitari wilayah cagar alam Pangandaran. Perahu pesiar dapat ditemukan di sepanjang pantai barat Pangandaran maupun pantai timur Pangandaran dengan total perahu sebanayk 130 unit yang terbagi ke dalam tujuh kelompok sesuai dengan wilayah pengelolaan yang berbeda-beda setiap kelompoknya atau memiliki batas pengoperasian perahu yang berbeda sesuai perjanjian yang telah disepakati.

Dalam menunjang kegiatan pariwisata, seperti alat pemancingan untuk memancing dan alat snorkling untuk berenang melihat keindahan bawah laut bagi para wisatawan yang menggunakan fasilitas pariwisata, kelompok perahu pesiar bekerjasama dengan pihak penyewaan alat tersebut bagi para wisatawan sehingga terjalin kerjasama antara pelaku usaha pariwisata di Desa Pangandaran.Setiap perahu pesiar terdiri dari juragan kapal atau pemilik kapal dengan anak buah kapalnya, dengan pembagian keuntungan sebanyak $50 \%$ bagi pemilik kapal dan sisanya bagi anak buah kapal dan pengeluaran untuk bahan bakar kapal dan konsumsi seluruh awak perahu. Kegiatan para awak perahu selain menyediakan fasilitas perahu pesiar juga masih melakukan kegiatan rutin mereka yaitu mencari ikan di laut dimulai pada pagi hari hingga menjelang siang hari, kemudian dilanjutkan dengan menyediakan fasilitas perahu pesiar bagi para wisatawan. Hal ini khusus dilakukan pada hari kerja, yaitu dari hari Senin hingga Jum'at, karena pada hari-hari tersebut jumlah wisatawan yang berkunjung ke Pangadaran tidak terlalu banyak. Ikan hasil tangkapan dapat mereka jual, dikonsumsi sendiri maupun diasinin karena ikan asin menjadi salah satu oleh-oleh yang banyak ditemukan di Pangandaran bagi para wisatawan. Pada hari Sabtu dan Minggu kelompok perahu pesiar tidak 
melakukan kegiatan penangkapan ikan di laut dan hanya melakukan kegiatan penyewaan perahu pesiar bagi para wisatawan dari pagi hingga sore hari dikarenakan pada hari-hari tersebut banyak jumlah wisatawan yang berkunjung ke Pangandaran.

Kelompok perahu pesiar juga berperan dalam pelestarian kebersihan lingkungan yaitu dengan menjaga kebersihan pantai dan laut. Hal ini dikarenakan kebersihan merupakan faktor utama dalam kelestarian obyek wisata. Setiap anggota kelompok selalu mengingatkan sesama anggotanya maupun para pengunjung untuk tidak membuang sampah sembarangan, tetapi hal ini susah dilakukan karena kurangnya kesadaran pengunjung terhadap kebersihan.

\section{Peluang Usaha dan Kerja Nelayan Pariwisata}

Usaha dan juga kerja di sektor pariwisata adalah berbagai pekerjaan yang dilakukan untuk memenuhi permintaan akan kebutuhan kegiatan wisata. Pengukuran dilakukan untuk melihat apakah terdapat usaha atau kerja tambahan dan macam usaha apa saja yang dilakukan oleh para nelayan yang aktif dalam kegiatan pariwisata selain usaha mereka sebagai kelompok perahu pesiar. Dikategorikan ke dalam nelayan perahu pesiar yang tidak ada tambahan usaha, dan perahu pesiar yang memiliki tambahan usaha lainnya. secara umum anggota kelompok perahu pesiar yang memiliki usaha dan kerja tambahan selain usaha perahu pesiar masih sangat sedikit, hal ini dikarenakan persaingan yang sangat ketat melihat sudah banyak sekali usaha yang dilakukan oleh masyarakat. Faktor lainnya dan yang utama adalah modal dalam menjalankan usaha, membutuhkan modal yang cukup banyak. Hal ini dibuktikan dengan rata-rata anggota kelompok perahu pesiar yang memiliki usaha tambahan adalah juragan perahu atau pemilik perahu yang secara tidak langsung memiliki tingkat ekonomi yang lebih baik daripada anggota kelompok yang tidak memiliki perahu meskipun terdapat juga beberapa anggota kelompok biasa yang memiliki usaha tambahan.

Usaha tambahan yang dijalankan oleh para anggota kelompok perahu pesiar yaitu usaha homestay, rumah makan dan warung/kios, dijalankan bersamasama dengan anggota keluarganya. Usaha-usaha tersebut dapat membantu dalam penambahan ekonomi keluarga mereka selain dari penghasilan sebagai jasa perahu pesiar ataupun mencari ikan di laut.

Melihat potensi dari pariwisata Pangandaran masih banyak peluang usaha yang dapat dijalankan oleh masyarakat khususnya anggota kelompok perahu pesiar seperti pedagang (kaki lima, oleh-oleh atau souvenir), akomodasi/penginapan, penyewaan transportasi (ojeg, becak, sepeda wisata), usaha rumah makan dan jasa kuliner, penyedia jasa/ penyewaan (sewa ban dan peralatan olahraga air)

\section{Analisis Hubungan Karakteristik Anggota Kelompok dengan Peran Kelompok Nelayan}

Terdapat empat peubah karakteristik anggota kelompok yang diuji hubungannya dengan peran kelompok nelayan, yaitu umur, tingkat pendidikan, jabatan kelompok dan juga lama keanggotaan. Karakteristik anggota kelompok merupakan faktor internal dari nelayan itu sendiri. Pengujian dilakukan untuk mengetahui apakah karakteristik anggota kelompok memiliki hubungan nyata dengan peran kelompok nelayan, khususnya dalam kegiatan pariwisata. Peran kelompok nelayan tersebut meliputi wahana kerjasama (kerjasama dalam pencarian informasi usaha sektor pariwisata, kerjasama dalam penyediaan komoditi atau peralatan usaha dan kerja, dan kerjasama dalam pengelolaan usaha kelompok) dan unit jasa penunjang. Hasil pengujian hubungan antara karakteristik anggota kelompok dengan peran kelompok nelayan disajikan secara ringkas pada Tabel 1.

Berdasarkan Tabel 1 dapat dijelaskan bahwa korelasi karakteristik anggota kelompok dengan peran kelompok nelayan sebagai wahana kerjasama menunjukkan hanya peubah umur yang memiliki hubungan sangat nyata $(\mathrm{p}<0,01)$, hal ini terjadi karena anggota kelompok yang cukup berumur atau sangat dewasa lebih dihormati, sehingga dalam menjalankan kerjasama terjalin dengan baik karena adanya perasaan menghargai. Anggota kelompok yang tergolong dewasa tersebut sangat aktif dalam menggerakkan anggota kelompok untuk bekerja, sehingga secara tidak langsung kerjasama tersebut dapat terjalin. Peubah tingkat pendidikan hanya memiliki hubungan nyata $(\mathrm{p}<0,05)$ dengan wahana kerjasama, karena berdasarkan hasil penelitian anggota kelompok yang berpendidikan tinggi hingga menempuh SMA, secara umum menyatakan wahana kerjasama kelompok cukup baik dan sangat 
Tabel 1 Korelasi Karakteristik Anggota Kelompok dengan Peran Kelompok Nelayan

\begin{tabular}{llcc}
\hline Karakteristik anggota kelompok & Koefisien korelasi & Wahana Kerjasama & Unit Jasa Penunjang \\
\hline Umur & $\mathrm{r}_{\mathrm{s}}$ & $0,61^{* *}$ & $0,43^{*}$ \\
Tingkat pendidikan & $\mathrm{r}_{\mathrm{s}}$ & $0,45^{*}$ & $-0,15$ \\
Jabatan di kelompok & $\chi^{r}$ & 2,80 & 3,61 \\
Lama keanggotaan & $\mathrm{r}_{\mathrm{s}}$ & 0,08 & 0,04 \\
\hline
\end{tabular}

Keterangan: $\quad * *$ berhubungan sangat nyata pada $\mathrm{p}<0,01$

* berhubungan nyata pada $\mathrm{p}<0,05$

baik. Orang-orang yang berpendidikan lebih tinggi mempengaruhi kinerja dalam kelompok tersebut. akan cenderung gampang menganalisis masalah dan Pengujian dilakukan untuk mengetahui apakah kemampuan berinteraksi dalam kerjasama kelompok elemen-elemen kelompok memiliki hubungan lebih baik, dimana kerjasama adalah hal yang nyata dengan peran kelompok nelayan, khususnya dibutuhkan dalam penyelesaian suatu pekerjaan dalam kegiatan pariwisata. Peran kelompok nelayan kelompok. Peubah jabatan di kelompok dan lama tersebut meliputi wahana kerjasama (kerjasama keanggotaan tidak memiliki hubungan yang nyata dalam pencarian informasi usaha pariwisata, dengan peran kelompok nelayan sebagai wahana kerjasama dalam penyediaan komoditiatau peralatan kerjasama. Korelasi karakteristik anggota kelompok dengan peran kelompok nelayan sebagai unit jasa penunjang menunjukkan hanya peubah umur yang memiliki hubungan nyata $(\mathrm{p}<0,05)$, karena anggota kelompok yang tergolong dewasa memiliki jumlah tanggungan keluarga yang lebih banyak dibanding dengan anggota kelompok yang tergolong muda, sehingga hal ini menyebabkan anggota-anggota yang tergolong dewasa berkeinginan untuk menambah penghasilan atau keuntungan dengan alternatif penambahan usaha penunjang lainnya. Peubah tingkat pendidikan, jabatan di kelompok, dan lama keanggotaan tidak memiliki hubungan yang nyata sama sekali dengan peran kelompok nelayan sebagai unit jasa penunjang.

\section{Analisis Hubungan Elemen-Elemen Kelompok dengan Peran Kelompok Nelayan}

Terdapat tiga buah peubah elemen-elemen kelompok yang diuji hubungannya dengan peran kelompok nelayan, yaitu kepemimpinan melalui peran pemimpin (mencetuskan ide atau sebagai seorang kepala, mengaktifkan anggota, mengawasi kegiatan, memberi semangat untuk mencapai tujuan, mewakili kelompok, dan memberi tanggung jawab), peranan tugas kelompok (penyetuspenyumbang, pencari informasi, pemberi informasi, pemberi pendapat, koordinator, pengkritik-penilai, dan penggerak) dan norma/aturan kelompok (bentuk aturan, pemahaman isi aturan, dan penerapan aturan). Elemen-elemen kelompok merupakan faktor yang usaha dan kerja, dan kerjasama dalam pengelolaan usaha kelompok. Hasil pengujian hubungan antara elemen-elemen kelompok dengan peran kelompok nelayan disajikan secara ringkas pada Tabel 2.

Berdasarkan Tabel 2 dapat dijelaskan bahwa korelasi elemen-elemen kelompok dengan peran kelompok nelayan sebagai suatu wahana kerjasama menunjukkan bahwa semua peubah elemen-elemen kelompok seperti peran pemimpin, peran tugas kelompok, dan norma/aturan kelompok memiliki hubungan yang sangat nyata dengan peran kelompok nelayan sebagai wahana kerjasama. Korelasi elemenelemen kelompok seperti peran pemimpin dan peran tugas kelompok memiliki hubungan yang sangat nyata dengan peran kelompok nelayan sebagai unit jasa penunjang, sedangkan norma/aturan kelompok tidak memiliki hubungan tersebut.

Terjadi hubungan yang sangat nyata $(\mathrm{p}<$ 0,01 ) antara peran pemimpin dengan peran kelompok nelayan sebagai wahana kerjasama, hal ini terjadi karenahampir semuaanggotakelompokberpandangan kinerja pemimpin mereka dirasa cukup baik, tentunya berhubungan secara langsung bagaimana pemimpin mengatur kerjasama dalam kelompok. Ketua kelompok dua, tiga dan enam melakukan perencanaan maupun pengambilan keputusan secara musyawarah yaitu melibatkan anggota kelompok ikut serta dalam kerjasama kelompok tersebut, sehingga kerjasama kelompok dirasa berjalan dengan cukup baik. Peubah peran pemimpin dengan unit jasa penunjang memperihatkan hubungan yang sangat nyata $(\mathrm{p}<$ $0,01)$, hal ini terjadi karena peran pemimpin yang 
Tabel 2 Korelasi Elemen-elemen Peran kelompok dengan Peran Kelompok Nelayan

\section{Peran Kelompok Nelayan (rs)}

\section{Elemen-elemen kelompok}

\begin{tabular}{lcc} 
& Wahana Kerjasama & Unit Jasa Penunjang \\
\hline Peran pemimpin & $0,73^{* *}$ & $0,60^{* *}$ \\
Peran tugas kelompok & $0,56^{* *}$ & $0,55^{* *}$ \\
Norma/aturan kelompok & $0,61^{* *}$ & 0,13 \\
\hline
\end{tabular}

Keterangan: **Berhubungan nyata pada $\mathrm{p}<0,01$

cukup baik berhubungan dengan pola pikir pemimpin untuk mencari keuntungan sebanyak-banyaknya bagi keperluan kelompoknya. Pengembangan unit jasa penunjang kelompok adalah cara bagi pemimpin untuk mengembangkan keuntungan kelompoknya, sehingga dianggap dapat memenuhi kebutuhan para anggotanya. Ketua kelompok tiga memiliki pandangan bahwa pengembangan usaha penunjang perlu dikembangkan, hal ini didukung dengan kemampuannya untuk menambahkan usaha tambahan seperti membuka warung dan homestay yang dikelola oleh keluarganya. Peubah peran tugas kelompok juga memperlihatkan hubungan yang sangat nyata $(\mathrm{p}<0,01)$ dengan wahana kerjasama karena karena dalam menjalankan kerja atau tugas kelompok sesama anggota baik pada kelompok dua, tiga dan enam memiliki pembagian tugas yang jelas dalam menjalankan kegiatan perahu pesiar, sehingga wahana kerjasama kelompok menurut para anggotanya dirasa sangat baik. Hubungan sangat nyata $(p<0,01)$ antara peran tugas kelompok dengan unit jasa penunjang, hal ini terjadi karena dalam menjalankan usaha perahu pesiar anggota kelompok merasa dapat menjalankan kerjasama yang baik, ditambah lagi banyaknya pengunjung ke Pangandaran tergantung musim sehingga peranan tugas kelompok mereka akan sangat besar jika pada musim banyaknya pengunjung yang datang. Faktorfaktor tersebut membuat keinginan mereka semakin tinggi untuk mengembangkan usaha penunjang lainnya untuk menambah pemasukan. Pada peubah norma/aturan kelompok dengan wahana kerjasama juga terjadi hubungan yang sangat nyata $(\mathrm{p}<0,01)$ hal ini karena sebagian besar anggota kelompok memiliki pemahaman yang cukup baik tentang norma/ aturan kelompok termasuk dalam penerapannya oleh masing-masing anggota kelompok dua, tiga dan enam, sehingga dalam pelaksanaan kerjasama dalam kelompok mengacu atau sesuai dengan aturan yang berlaku.

Berdasarkan data yang dijelaskan di atas, maka hipotesis penelitian (H1) kedua yang menyebutkan "terdapat hubungan nyata antara elemen-elemen kelompok yaitu kepemimpinan melalui peran pemimpin, peranan tugas kelompok, dan norma/ aturan kelompok dengan peran kelompok nelayan sebagai wahana kerjasama dan unit jasa penunjang," diterima terkecuali peubah norma/aturan kelompok dengan peran kelompok nelayan sebagai unit jasa penunjang.

\section{Analisis Hubungan Karakteristik Anggota Kelompok dengan Elemen-Elemen Kelompok}

Terdapat empat peubah karakteristik anggota kelompok yang diuji hubungannya dengan elemenelemen kelompok yaitu umur, tingkat pendidikan, jabatan kelompok dan juga lama keanggotaan. Karakteristik anggota kelompok merupakan faktor internal dari anggota kelompok tersebut. Pengujian dilakukan untuk mengetahui apakah karakteristik anggota kelompok memiliki hubungan nyata dengan elemen-elemen kelompok, khususnya dalam kegiatan pariwisata. Elemen-elemen kelompok meliputi yaitu kepemimpinan melaluiperan pemimpin (mencetuskan ide atau sebagai seorang kepala, mengaktifkan anggota, mengawasi kegiatan, memberi semangat untuk mencapai tujuan, mewakili kelompok, dan memberi tanggung jawab), peranan tugas kelompok (penyetus-penyumbang, pencari informasi, pemberi informasi, pemberi pendapat, koordinator, pengkritikpenilai, dan penggerak) dan norma/aturan kelompok (bentuk aturan, pemahaman isi aturan, dan penerapan aturan). Hasil pengujian hubungan antara karakteristik anggota kelompok dengan elemen-elemen kelompok disajikan secara ringkas pada Tabel 3.

Berdasarkan Tabel 3 dapat dijelaskan bahwa korelasi antara karakteristik dari anggota kelompok 
Tabel 3 Korelasi Karakteristik Anggota Kelompok dengan Elemen-elemen Kelompok

\begin{tabular}{lcccc}
\hline $\begin{array}{c}\text { Karakteristik } \\
\text { anggota } \\
\text { kelompok }\end{array}$ & $\begin{array}{c}\text { Koefisien } \\
\text { korelasi }\end{array}$ & $\begin{array}{c}\text { Elemen-elemen } \\
\text { kelompok pemimpin }\end{array}$ & Peranan Tugas Kelompok & Norma/aturan kelompok \\
\hline $\begin{array}{l}\text { Umur } \\
\text { Tingkat }\end{array}$ & rs & 0,33 & $0,48^{* *}$ & $0,41^{*}$ \\
pendidikan & rs & 0,13 & 0,21 & $0,52^{* *}$ \\
$\begin{array}{l}\text { Jabatan di } \\
\text { kelompok }\end{array}$ & $\chi^{r}$ & 1,75 & 0,84 & 5,04 \\
$\begin{array}{l}\text { Lama } \\
\text { keanggotaan }\end{array}$ & rs & 0,10 & $-0,11$ & 0,05 \\
\hline Keterangan: & $* *$ berhubungan sangat nyata pada $\mathrm{p}<0,01$ &
\end{tabular}

* berhubungan nyata pada $\mathrm{p}<0,05$

denganelemen-elemendalamkelompokmenunjukkan peubah umur dengan peran tugas kelompok memiliki hubungan yang sangat nyata $(\mathrm{p}<0,01)$ hal in terjadi karena Pada kelompok enam, anggota yang berusia dewasa terlihat lebih aktif mencari dan menawarkan jasa perahu pesiar kepada pengunjung dibandingkan anggota yang tergolong muda, hal ini menunjukkan peranan yang berbeda antar anggota kelompok yang berbeda umur. Peubah tingkat pendidikan dengan norma/aturan kelompok juga memiliki hubungan yang sangat nyata $(\mathrm{p}<0,01)$, karena lebih dari $40 \%$ anggota kelompok menamatkan pendidikan hingga jenjang SMP dan itu digolongkan ke dalam tingkat pendidikan yang sedang atau cukup tinggi, sehingga pemahaman tentang norma/aturan kelompok yang berlaku sudah dapat dipahami dengan baik. Peubah umur dengan norma/aturan kelompok memiliki hubungan yang nyata $(\mathrm{p}<0,05)$, hal ini terjadi karena berdasarkan data yang didapat menunjukkan anggota yang tergolong ke dalam dewasa awal dan dewasa akhir memiliki tingkat pemahaman yang cukup tinggi terhadap norma/aturan kelompok dibandingkan dengan anggota yang tergolong muda. Hal ini memperlihatkan hubungan antara umur yang berbeda dengan norma/aturan kelompok. Pada peubahpeubah lainnya tidak memiliki hubungan nyata satu sama lainnya.

Berdasarkan data yang dijelaskan di atas, maka hipotesis penelitian (H1) ketiga yang menyebutkan"terdapat hubungan nyata antara karakteristik anggota kelompok dengan elemenelemen kelompok," diterima untuk peubah umur dengan peubah peranan tugas kelompok dan peubah norma/aturan kelompok, dan peubah tingkat pendidikan dengan peubah norma/aturan kelompok.

\section{Analisis Hubungan Peran Kelompok Nelayan dengan Peluang Usaha Dan Kerja}

Peran kelompok nelayan meliputi wahana kerjasama (kerjasama dalam pencarian informasi usaha pariwisata, kerjasama dalam penyediaan komoditi atau peralatan usaha dan kerja, dan kerjasama dalam pengelolaan usaha kelompok) dan unit jasa penunjang (peran kelompok untuk melakukan usaha tambahan atau usaha lain selain usaha pokoknya seperti pengembangan usaha penunjang di sektor perdagangan, akomodasi, transportasi, makanan, dan penyewaan peralatan olahraga air). Pengujian dilakukan untuk mengetahui hubungan peran kelompok nelayan dengan peluang usaha dan kerja. Usaha dan kerja di sektor pariwisata adalah berbagai pekerjaan yang dilakukan untuk memenuhi permintaan akan kebutuhan kegiatan wisata. Dalam hal ini yang dilihat apakah terdapat usaha atau kerja tambahan dan macam usaha apa saja yang dilakukan oleh para nelayan yang aktif dalam kegiatan pariwisata selain usaha mereka sebagai nelayan dan kelompok perahu pesiar. Dikategorikan ke dalam perahu pesiar yang tidak ada tambahan usaha, dan perahu pesiar yang memiliki tambahan usaha lainnya. Hasil pengujian hubungan antara peran kelompok nelayan dengan peluang usaha dan kerja disajikan secara ringkas pada Tabel 4.

Berdasarkan Tabel 4 dapat dijelaskan bahwa peran kelompok nelayan sebagai wahana kerjasama memiliki hubungan yang nyata $(\mathrm{p}<0,05)$ dengan peluang usaha dan kerja, hal in terjadi karena hasil penelitian ini menunjukkan bahwa kerjasama di dalam kelompok dua, tiga dan enam dirasa cukup baik dalam pengelolaan perahu pesiar yang membuat anggota kelompok berkeinginan mengembangkan usaha selain bergantung sebagai nelayan maupun 
Tabel 4 Korelasi Peran Kelompok Nelayan dengan Peluang Usaha dan Kerja

\begin{tabular}{|c|c|}
\hline Peran kelompok nelayan & Peluang usaha dan kerja $\left(\chi^{2}\right)$ \\
\hline Wahana kerjasama & $6,88^{*}$ \\
\hline Unit jasa penunjang & $11,11 * *$ \\
\hline
\end{tabular}

perahu pesiar. Beberapa anggota kelompok melihat kebutuhan pariwisata yang semakin berkembang di Pangandaran. Hal ini tentunya berhubungan di antara dua peubah tersebut. Pada peran kelompok nelayan sebagai unit jasa penunjang memiliki hubungan yang sangat nyata $(\mathrm{p}<0,01)$ dengan peluang usaha dan kerja, karena karena unit jasa penunjang adalah peran kelompok melakukan usaha di luar usaha pokoknya, hal ini menunjukkan hubungan yang nyata terhadap peluang usaha dan kerja dalam kegiatan pariwisata, hal ini dibuktikan berdasarkan data yang didapat bahwa peran kelompok nelayan untuk meningkatkan peran kelompok dalam unit jasa penunjang dalam kategori sedang yaitu sebesar 69,44 persen responden. Hal ini berhubungan dengan adanya 10 orang anggota kelompok yang melakukan usaha di luar usaha pokoknya selain sebagai nelayan maupun perahu pesiar, seperti homestay, rumah makan, dan warung/kios, karena merasa butuhnya usaha tambahan untuk memenuhi kebutuhan. Terjadinya hal tersebut juga didukung dengan kemampuan anggota kelompok dalam melihat kesempatan dan kebutuhan yang semakin meningkat bagi para wisatawan tersebut.

\section{Kesimpulan}

Kelompok nelayan khususnya kelompok perahu pesiar yang menjadi obyek penelitian kali ini berperan dalam penyediaan jasa perahu pesiar. Perahu pesiar menjadi sarana pariwisata alternatif yang ditawarkan untuk menikmati keindahan Pangandaran dan sekitarnya. Selain sebagai nelayan, usaha perahu dapat meningkatkan pendapatan ekonomi mereka. Perahu pesiar yang dilakukan oleh kelompok nelayan tersebut berperan dalam pengembangan pariwisata di Pangandaran karena menawarkan alternatif pariwisata yang jarang ditemukan di tempat lainnya Terdapat hubungan nyata antara karakteristik anggota kelompok dengan peran kelompok nelayan, seperti umur dengan wahana kerjasama dan unit jasa penunjang, dan juga tingkat pendidikan dengan wahana kerjasama. Peran pemimpin memiliki hubungan nyata dengan peran kelompok nelayan sebagai wahana kerjasama dan unit jasa penunjang. Peranan tugas kelompok juga memiliki hubungan nyata dengan wahana kerjasama dan unit jasa penunjang. Norma/aturan kelompok memiliki hubungan nyata dengan peran kelompok nelayan sebagai wahana kerjasama.

Usaha dan kerja yang dilakukan oleh nelayan perahu pesiar selain sebagai nelayan dan menawarkan jasa perahu pesiar adalah penyewaan homestay yaitu rumah tinggal yang dimiliki oleh para nelayan, rumah makan seperti warteg atau rumah makan prasmanan, dan warung atau kios yang menjajakan kebutuhan pokok, makanan ringan maupun minuman. Usaha tersebut tidak membutuhkan keterampilan khusus dan modal usaha yang besar sehingga terjangkau oleh para nelayan dan keluarganya. Peran kelompok nelayan sebagai wahana kerjasama dan unit jasa penunjang membuktikan bahwa peran kelompok memberikan kesempatan dan menciptakan keinginan anggota kelompok untuk mengembangkan usaha tambahan atau lainnya.

\section{Daftar Pustaka}

[BPS] Badan Pusat Statistik. 2012. Istilah Statistik. [Diunduh 5 Januari 2013]

Bungin B. 2008. Sosiologi Komunikasi: Teori, Paradigma, dan Diskursus Teknologi Komunikasi Masyarakat. Jakarta: Kencana Prenada Media Group

Dewan Perwakilan Rakyat Republik Indonesia dan Presiden Republik Indonesia. Undangundang Republik Indonesia No. 13 Tahun 2003. [Diunduh 18 Februari 2013]

Dewan Perwakilan Rakyat Republik Indonesia dan Presiden Republik Indonesia. Undangundang Republik Indonesia No. 31 Tahun 2004. [Diunduh 5 Januari 2013]

Dewan Perwakilan Rakyat Republik Indonesia dan Presiden Republik Indonesia. Undang-undang Republik Indonesia No. 10 Tahun 2009. http:// 
www.depdagri.go.id [Diunduh 5 Januari 2013].

Dewan Perwakilan Rakyat Republik Indonesia dan Presiden Republik Indonesia. Undangundang Republik Indonesia No. 11 Tahun 2009. http://www.kemsos.go.id/unduh/UU-KesosNo11-2009.pdf. [Dikutip 5 Januari 2013]

Goldberg AA., Larson CE. 2006. Komunikasi Kelompok: Proses-Proses Diskusi dan Penerapan; Penerjemah, Koesdarini S., Gary R. Jusuf. Jakarta : Penerbit Universitas Indonesia (UI-Press).

Ibrahim JT. 2002. Sosiologi Pedesaan. Malang: UMM Pers

Ibrahim JT. 2002. Sosiologi Pedesaan. Malang: UMM Pers

Kamus Besar Bahasa Indonesia. 2012. Kamus Besar Bahasa Indonesia (KBBI). http://www.kbbi. web.id/ [Dikutip 19 Februari 2013]

Kementrian Kebudayaan dan Pariwisata. 2013. Ranking Devisa Pariwisata.http://www.budpar. go.id/userfiles/file/.[Dikutip 4 maret 2013]. 17

Menteri Kelautan dan Perikanan Republik Indonesia. Keputusan Menteri Kelautan dan Perikanan Republik Indonesia Nomor KEP.14/MEN/2012. http://infohukum.kkp.go.id/fileskepmen 02012. pdf [Diunduh 2 Januari 2013]

Rakhmat J. 1997. Metode Penelitian Komunikasi. Bandung (ID): Remaja Rosdakarya. 184 hal.

Riduwan, Sunarto. 2011. Pengantar Statistika. Bandung (ID): Alfabeta

Robbins SP. 2002. Prinsip-prinsip Perilaku Organisasi. Jakarta (ID): Erlangga.

Saleh A. 2009. Bahan Kuliah komunikasi Kelompok. Tidak dipublikasikan. Departemen Sains Komunikasi dan Pengembangan Masyarakat. Fakultas Ekologi Manusia: Institut Pertanian Bogor Santosa S. 2006. Dinamika Kelompok (Edisi Revisi).Jakarta (ID): PT Bumi Aksara

Satria A. 2002. Pengantar Sosiologi Masyarakat Pesisir. Jakarta (ID): Pustaka CIDESINDO

Singarimbun M., Effendi S. 2008. Metode Penelitian Survei. Jakarta (ID): LP3ES 